\title{
Phytochemistry and Antimicrobial Activities of Different Varieties of Banana (Musa Acuminate) Peels Available in Quetta City
}

\author{
Farrukh Bashir ${ }^{1}$, Arifa Hassan ${ }^{1}$, Ayesha Mushtaq ${ }^{1 *}$, Sabeena Rizwan ${ }^{1}$, Uzma Jabeen ${ }^{1}$, \\ Aamir Raza', Shaista Anjum ${ }^{3}$, Ayeesha Masood ${ }^{3}$ \\ ${ }^{1}$ Faculty of Basic Sciences, Sardar Bahadur Khan Women's University Quetta, Pakistan \\ ${ }^{2}$ PCSIR Laboratory, Quetta, Pakistan \\ ${ }^{3}$ Faculty of Life Sciences, University of Balochistan, Quetta, Pakistan
}

Received: 22 February 2020

Accepted: 14 May 2020

\begin{abstract}
Banana (Musa acuminate) contains peels which are rich in important bioactive compounds which makes them greatly significant for therapeutic treatments. For studying phytochemical and antimicrobial properties of the peels, six varieties of bananas were chosen from Quetta. Carbohydrates, tannins, steroids, terpenoids, flavonoids, glycosides and phenols were found in the six solutions of banana peels samples through phytochemical screening. Evaluation of antibacterial activity of peel solutions through agar disc diffusion method showed inhibition zone diameters of $19 \mathrm{~mm}$ and $17 \mathrm{~mm}$ against Escherichia coli and Staphylococcus aureus respectively. Poisoned food technique and agar well assays were used for the antifungal activity but the BP solutions against Aspergillus niger were not effective. In addition to this, proximate analysis was also carried out to characterize the peel powder and the results showed $6-11 \%$ moisture, $60-75 \%$ volatile matter, $13-25 \%$ ash and 2-9\% fixed carbon contents. For the analysis of elements (Iron and Copper) concentrations, Atomic Absorption Spectrophotometer was utilized which concluded that banana peels could be excellent therapeutic agent.
\end{abstract}

Keywords: antimicrobial, banana, peel, phytochemical, proximate

\section{Introduction}

In some fruits, peels contain higher vitamins, better biological activities, minerals and essential nutrients than other parts [1-3]. Banana fruit is highly nutritious possessing essential phytonutrients such as phenolic

*e-mail: ayeshamushtaq2000@yahoo.com compounds, biogenic amines, carotenoids, flavonoids, vitamins and several minerals having many therapeutic benefits [4]. Apart from nutritive values, banana fruit also contains medicinal values such as pulp and peel that have antibiotic and antifungal components. The peel constituting approximately $40 \%$ of banana weight, has high proteins, essential amino acids, water content, dietary fiber and polyunsaturated fatty acids $[5,6]$. Banana peel is also used as a bio-sorbent to remove toxic elements from water $[7,8]$ due to its availability, 
inexpensiveness and ecofriendly bio-materials [9]. To produce alcohol, methane and biomass different studies suggested the utilization of banana peel [10]. In addition to this, phytochemical compounds are found in excess in banana peels [11].

Phytochemicals are valuable bioactive constituents in plants [12] that protect against diseases by working with fibers and nutrients [13] making them significant for curing human diseases [14]. On almost all types of microorganisms, the phytochemicals of various chemical classes have inhibitory effects [15]. Plants discovery having bioactive substances are extensively progressing to produce antimicrobial drugs that can kill new microorganisms [16].

Plants that are potential sources of microbial inhibitors, are getting great importance [17] because to synthetic antibiotics the bacteria became resistant [18]. Due to huge production and extreme utilization of banana, a large quantity of banana peels is produced which increases pollution since no feasible utilization has been attempted [19]. Several applications such as low-cost bio sorbents, biofuels, biochemicals and other valuable products can be generated from banana biomass [20] via proximate analysis [19]. Therefore, to determine the fixed carbon, ash, moisture and volatile matter contents of banana peel powder, proximate analysis is carried out.

Not only vitamins and bioactive compounds but trace elements are also associated with the medicinal value of banana peel even in small amounts [21]. Thus, in this research Atomic Absorption Spectrophotometer was used to determine trace elements quantity such as iron $(\mathrm{Fe})$ and copper $(\mathrm{Cu})$.

\section{Experimental}

\section{Materials}

In July and August 2018, from different areas of Quetta six varieties of bananas were chosen and labelled as sample 1, sample 2, sample 3, sample 4, sample 5 and sample 6 respectively for ease. All the required chemicals were bought from Merck.

\section{Preparation of Banana Peel Powder}

Some peels of all samples were washed thoroughly with distilled water and dried. Later with mechanical blender they were grounding into powder and sieved, the powdered formed were kept into airtight containers [22].

\section{Preparation of Solutions of Banana Peel}

For the peel paste fresh peels of banana were chopped then ground through an electrical blender. From each sample $10 \mathrm{mg}$ paste was dissolved in 50 $\mathrm{ml}$ of DMSO and shaken vigorously for two to three hours. After filtration the solutions obtained were utilized for antimicrobial activities and phytochemical analysis.

\section{Phytochemical Analysis}

Utilizing standard methodology, the phytochemical analysis was carried out in solution form for the presence and identification of bioactive constituents in Banana peels $[12,22]$.

\section{Carbohydrates Tests}

\section{Fehling's Test}

Reducing sugars were indicated when Fehling's solution A and B and test solutions were treated which formed brown precipitates.

2. Molisch's Test

In test solutions, alcoholic $\alpha$-naphthol solution $(10 \%)$ was added drop wise followed by the addition of conc. $\mathrm{H}_{2} \mathrm{SO}_{4}$ which confirmed the carbohydrates and glycosides by bluish violet zone formation.

3. Test for Cardiac Glycosides

- Cardiac glycosides were found to be present as brown ring formed at the interface when $3 \mathrm{ml}$ test solutions and glacial acetic acid $(3 \mathrm{ml})$ were reacted, then $5 \% \mathrm{FeCl}_{3}$ solution was added drop wise and conc. $\mathrm{H}_{2} \mathrm{SO}_{4}(2 \mathrm{ml})$ was carefully added.

- In Baljit's test, $3 \mathrm{ml}$ test solutions were reacted with Baljit's reagent $(10 \% \mathrm{NaOH} 5 \mathrm{ml}$ and $1 \%$ picric acid $95 \mathrm{ml}$ ) which confirmed presence of cardiac glycoside by the red colour of solution.

\section{Test for Glycosides}

1. Liebermann's Test

A blue colour changes into green, when $3 \mathrm{ml}$ test solutions were treated with chloroform $(2 \mathrm{ml})$ and acetic acid $(2 \mathrm{ml})$ which indicated glycosides.

\section{Salkowski's Test}

Reddish-brown steroidal ring confirmed glycosides when chloroform and test samples were reacted followed by addition of sulphuric acid.

\section{Tannins Test}

$2 \mathrm{ml}$ test samples and $2 \mathrm{ml}$ distilled water were mixed and ferric chloride 5\% solution was poured drop wise. Green precipitates indicated tannins.

\section{Steroids Test}

$2 \mathrm{ml}$ test solutions were poured in $2 \mathrm{ml} \mathrm{CHCl}_{3}$ and $2 \mathrm{ml}$ conc. $\mathrm{H}_{2} \mathrm{SO}_{4}$ which detected steroids when in lower layer of chloroform, a red colour was formed. 


\section{Test for Flavonoids}

$3 \mathrm{ml}$ test solutions and $3 \mathrm{ml}$ lead acetate solution $(10 \%)$ were added. Flavonoids were detected when brown or yellow precipitates formed.

\section{Terpenoids Test}

Terpenoid was detected through reddish-brown colour interface when $3 \mathrm{ml} \mathrm{CHCl}$ and $2 \mathrm{ml}$ test solutions were treated followed by addition of $2 \mathrm{ml}$ conc. $\mathrm{H}_{2} \mathrm{SO}_{4}$.

\section{Phenols Test}

1. Intense violet colour indicated phenols when ferric chloride solution $(1 \mathrm{ml})$ and test solutions $(2 \mathrm{ml})$ were mixed.

2. Bulky ppts were formed when test solutions $(3 \mathrm{ml})$ and lead acetate $10 \%$ solution $(5 \mathrm{ml})$ were treated which confirmed the phenols.

3. In Ellagic test $3 \mathrm{ml}$ test solutions, 5\% acetic acid and $5 \% \mathrm{w} / \mathrm{v}$ sodium nitrite were added. Phenols are indicated when Brown precipitates formed.

\section{Test for Alkaloid}

1. Mayer's reagent

Solution A: mercuric chloride $(0.35 \mathrm{~g})$ and distilled water $(60 \mathrm{ml})$ were dissolved.

Solution B: Distilled water $(20 \mathrm{ml})$ and KI $(5 \mathrm{~g})$ were dissolved.

Volume was raised till $100 \mathrm{ml}$ after mixing solutions $\mathrm{A}$ and $\mathrm{B}$.

2. Wagner's Reagent

Potassium iodide $(6 \mathrm{~g})$ and iodine $(2 \mathrm{~g})$ were added in $100 \mathrm{ml}$ dist. $\mathrm{H}_{2} \mathrm{O}$.

The alkaloids presence was evidenced from turbidity when $2 \mathrm{ml}$ test solutions and $3 \mathrm{ml} \mathrm{HCl}(1 \%)$ were added and warmed, then in the mixtures Wagner's and Mayer's reagents were poured separately.

\section{Test for Xanthoprotein}

Ammonia solution $(1 \mathrm{ml})$, conc. nitric acid $(1 \mathrm{ml})$ and test solutions $(4 \mathrm{ml})$ when treated reddish orange precipitates formed that indicated xanthoprotein.

\section{Sodium Hydroxide (NaOH) Test}

A yellow solution is obtained when test solutions (3 ml) and $\mathrm{NaOH}$ were added. The solution was decolourized by addition of dilute $\mathrm{HCl}$ drop wise which confirms $\mathrm{NaOH}$ presence.

\section{Proximate Analysis}

Moisture, volatile matter, ash and fixed carbon contents of all samples of banana peel were calculated through proximate analysis. ASTM: D3173 procedure was utilized to find moisture content. The crucibles were kept at $105^{\circ} \mathrm{C}$ in oven for one hour after washing thoroughly and then cooled in a desiccator. Each crucibles weight was noted and peel powder such as $0.41 \mathrm{~g}$ sample $1,0.84 \mathrm{~g}$ sample $2,0.62 \mathrm{~g}$ sample $3,0.54$ g sample 4, $0.66 \mathrm{~g}$ sample 5 and $0.73 \mathrm{~g}$ sample 6 were added in each crucible respectively and the total weight was recorded. Then crucibles were placed at $105^{\circ} \mathrm{C}$ to $110^{\circ} \mathrm{C}$ in a preheated oven for 90 mins and cooled in a desiccator. Later, moisture contents were calculated by recording the crucibles weight [23]. Procedure ASTM: D3175 was used to determine volatile matter. The airdried samples were heated in muffle furnace at $950^{\circ} \mathrm{C}$ for seven minutes. Later they were shifted in desiccator for cooling and the weight was noted. To determine the contents of ash ASTM: D3174-12 procedure was utilized. In muffle furnace, the crucibles containing samples were kept at $850^{\circ} \mathrm{C}$ for 2 or 3 hours and then placed in desiccator for cooling and weight. Fixed carbon content was gained by subtracting sum of the moisture (M), volatile matter (V/M) and ash (A) contents percentages. i.e.

$$
\begin{gathered}
\text { Fixed carbon }=100-(\% \text { moisture } \\
+\% \text { volatile matter }+\% \text { ash })
\end{gathered}
$$

\section{Antibacterial Assay}

Disc diffusion assay was used for antibacterial activity [24] and bacterial species used were gramnegative $E$. coli and gram-positive $S$. aureus. Muller Hinton Agar (MHA) $33.9 \mathrm{~g}$ and distilled water $(1000 \mathrm{ml})$ were dissolved for the medium then autoclaved for 15 minutes at $121^{\circ} \mathrm{C}(15 \mathrm{psi})$. Later, poured the molten medium on Petri dishes and left for solidification. Similarly, nutrient agar (13 g) and distilled water $(1000 \mathrm{ml})$ were dissolved and autoclaved for 15 minutes at $121^{\circ} \mathrm{C}$. For positive control ciprofloxacin discs were utilized. On nutrient agar plates bacterial cultures were inoculated and left overnight at $37^{\circ} \mathrm{C}$. In normal saline few colonies from the fresh bacterial culture were dissolved and with 0.5 MacFarland standard the turbidity was compared. A cotton swab was dip in bacterial suspension and pressed against the tube wall to avoid excess inoculum. MHA plates were inoculated thoroughly by streaking with the swab. Filter paper discs $(6 \mathrm{~mm})$ were soaked in test solutions $(15 \mathrm{uL})$ and placed on dried and inoculated plate. The discs were pushed down lightly for even contact with agar surface and the minimum center-center discs distance was $24 \mathrm{~mm}$. The plates were incubated at $37^{\circ} \mathrm{C}$ and after 24 hours inhibition zones were measured in millimetres.

\section{Screening of Antifungal Activity}

With few modifications poisoned food technique [25] and agar well assay [26] were used for antifungal activity. 
Potato Dextrose Broth was obtained when potato slices $(300 \mathrm{~g})$ were boiled in $1000 \mathrm{ml}$ distilled water for thirty minutes and decanted via cheesecloth. $20 \mathrm{~g}$ Glucose was added and volume was raised to $1 \mathrm{~L}$ then autoclaved. Later $20 \mathrm{~g}$ agar was added, autoclaved again at $121^{\circ} \mathrm{C}$ (15 psi) for 15 minutes and poured on Petri plates. Aspergillus niger was grown in PDA medium and left for 7 days at $28^{\circ} \mathrm{C}$.

\section{Poisoned Food Technique}

In laminar air flow, test solutions $(500 \mu \mathrm{L})$ with sterile filter syringe and molten PDA $30 \mathrm{ml}$ were poured on sterilized petri plates then shaken slightly to mix test solution and agar and left for 10 minutes. For two days the petri plates including control plate were placed at $28^{\circ} \mathrm{C}$ in incubator to check sterility. Aspergillus niger was inoculated to the centre of the petri plates of control plate and test samples and incubated again at $28^{\circ} \mathrm{C}$. After 4 or 7 days or at least 14 days, observed the fungal growth and compared against control plate.

\section{Agar Well Assay}

$30 \mathrm{ml}$ PDA was poured on petri plates and left to solidify then incubated for 24 hours at $28^{\circ} \mathrm{C}$. $6 \mathrm{~mm}$ well was bored with sterile borer and test solutions $(0.5 \mathrm{ml})$ was poured. Using sterilized needle, Aspergillus niger was applied then incubated for 48 hours. Zone of inhibition were measured in $\mathrm{mm}$.

\section{Atomic Absorption Spectrophotometer}

In banana peel samples $\mathrm{Fe}$ and $\mathrm{Cu}$ were examined by AAS. Wet digestion method was used for samples mineralization utilizing mixture of three strong acids i.e. nitric acid, sulphuric acid and hypochlorous acid.

\section{Digestion Method}

In wet digestion method, $0.25 \mathrm{~g}$ peel powder and $\mathrm{HNO}_{3}: \mathrm{H}_{2} \mathrm{SO}_{4}: \mathrm{HClO}_{4}$ of 5:1:0.5 ratios were taken in flasks then heated on a hot plate at $85^{\circ} \mathrm{C}$. White fumes confirmed that digestion was completed then distilled water was poured for cooling the solutions and transferred to volumetric flasks to raise the volume up to the mark. After filtration, the solutions were analysed to detect elements via atomic absorption spectrophotometer. Dilutions of various concentrations were prepared from analytical grade stock standards of $1000 \mathrm{ppm}$ for calibration. Selective hollow cathode lamps with acetylene/air flame was utilized in AAS.

\section{Results and Discussion}

\section{Phytochemical Analysis}

Table 1 presents the phytochemical compounds present in all banana peels samples. In all samples
Table 1. Phytochemical analysis of Banana peel solutions.

\begin{tabular}{|c|c|c|c|c|c|c|}
\hline \multirow{2}{*}{ Test } & \multicolumn{5}{|c|}{ Samples } \\
\cline { 2 - 7 } & 1 & 2 & 3 & 4 & 5 & 6 \\
\hline $\begin{array}{c}\text { Carbohydrates } \\
\text { Molisch's Test }\end{array}$ & + & + & + & + & + & + \\
\hline Fehling's Test & + & + & + & + & + & + \\
\hline Cardiac Glycosides & + & + & + & + & + & + \\
\hline Baljit's Test & + & + & + & + & + & + \\
\hline $\begin{array}{c}\text { Glycosides } \\
\text { Lieberman's Test }\end{array}$ & - & - & + & - & - & + \\
\hline Salkowski's Test & + & + & - & + & + & + \\
\hline Steroids & + & + & + & + & + & + \\
\hline Tannins & + & + & + & + & + & + \\
\hline Flavonoids & + & + & + & + & + & + \\
\hline Terpenoids & + & - & - & + & + & + \\
\hline $\begin{array}{c}\text { Phenols } \\
\text { With FeCl }\end{array}$ & + & + & + & + & + & + \\
\hline With Lead acetate & + & + & + & + & + & + \\
\hline Ellagic Test & - & - & - & - & - & - \\
\hline Xanthoprotein & - & - & - & - & - & - \\
\hline Alkaloids & - & - & - & - & - & - \\
\hline Wagner's Test & - & - & - & - & - & - \\
\hline NaOH & + & - & - & - & + & - \\
\hline Present & - & Absent & & \\
\hline
\end{tabular}

glycosides, carbohydrates, tannins, flavonoids, phenols and steroids were detected. However, sodium hydroxide test was found positive only in solution of samples 1 and 5 whereas terpenoids were absent in solutions of sample 2 and 3. Xanthoprotein and Alkaloids were not found in all samples.

Several studies reported different bioactive compounds such as flavonoids, carbohydrate, proteins, sugar, quinone, ketose, terpenoids, cardiac glycoside, saponins and phenols in various Musa genus species [27]. In peel extracts of Musa sapientum, alkaloids, tannins, saponins and steroids were also detected by Siddique et al., and Prakash et al., in the analysis of phytochemicals $[26,28]$. The antioxidant and antimicrobial properties of plants are because of flavonoids, tannins and alkaloids and these are also detected in the present work.

\section{Proximate Analysis}

The nutritional composition and contents of volatile matter, ash, moisture and fixed carbon of crude oil is provided by proximate analysis which impacts combustion capability of plants [23]. The values of peel 
Table 2. Proximate analysis of banana peel powder.

\begin{tabular}{|c|c|c|c|c|c|c|}
\hline Samples & Moisture & Volatile matter & Ash & Fixed carbon & $\begin{array}{c}\mathrm{Cu} \\
(\mathrm{ppm})\end{array}$ & $\mathrm{Fe}(\mathrm{ppm})$ \\
\hline Sample 1 & $7.50 \%$ & $75.61 \%$ & $13.97 \%$ & $2.92 \%$ & 0.2681 & 3.5438 \\
\hline Sample 2 & $9.45 \%$ & $60.97 \%$ & $20.40 \%$ & $9.18 \%$ & 0.3065 & 0.8421 \\
\hline Sample 3 & $8.11 \%$ & $61.26 \%$ & $25.82 \%$ & $4.81 \%$ & 0.3448 & 2 \\
\hline Sample 4 & $6.98 \%$ & $72.84 \%$ & $15.72 \%$ & $4.46 \%$ & 0.3448 & 1.4035 \\
\hline Sample 5 & $8.20 \%$ & $65.04 \%$ & $20.27 \%$ & $6.49 \%$ & 0.3065 & 0.5964 \\
\hline Sample 6 & $8.02 \%$ & $65.52 \%$ & $21.07 \%$ & $5.39 \%$ & 0.4597 & 0.5263 \\
\hline
\end{tabular}

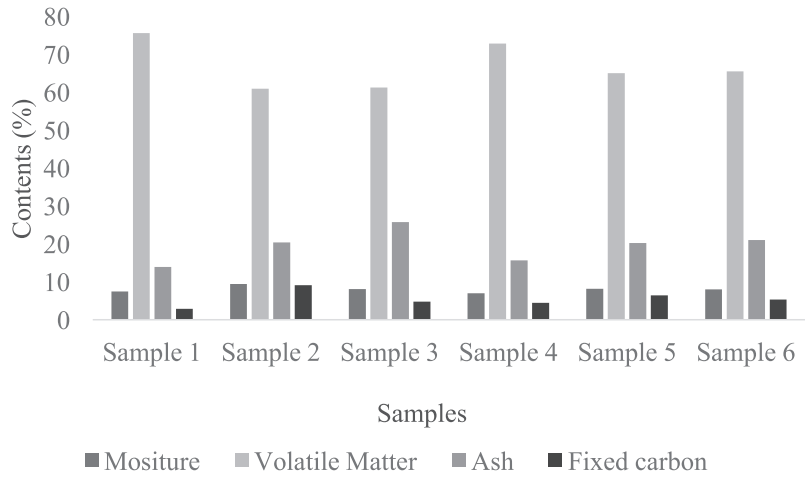

Fig. 1. Proximate analysis of Banana peel powder.

samples are presented in Table 2 and Fig. 1 which shows prominent difference in all contents of the samples. The dried samples moisture contents ranging from $6-11 \%$ are worthy for biomass pyrolysis as pyrolysis efficiency and fuel energy values are negatively impacted by higher moisture contents [19]. In this research moisture content of the six test samples varied from $6-9 \%$ with sample 2 $(9.45 \%)$ expressing highest moisture content and sample $4(6.98 \%)$ showing lowest moisture content. In banana peel waste $11.56 \%$ and $6-10 \%$ moisture contents were reported in literature $[19,20]$ respectively. It is reported that low moisture content decreases the risk of molds growth and for a longer time sample can also be stored [23].

Banana peel wastes easily ignite due to high volatile matter contents. Kabenge et al., [19] recorded $88.02 \%$ volatile matter content due to the presence of the proteins, carbohydrates and lipids nutrients sources. Similarly, in the present work, the contents of volatile matter ranged from $60-75 \%$ whereas, samples 1 and 4 showed the higher values $75.61 \%$ and $72.84 \%$ respectively.

Ash is a significant mineral and micronutrient source of soil [20] and in the present work it ranged between $13-25 \%$ as shown in Table 2. It is reported that banana peel wastes ash contents with minimum ranges are ideal bioenergy converters for gasification and pyrolysis processes [19]. Similarly, fixed carbon contents are also shown in Table 2 where sample 2 with a maximum
9.18\% contents of fixed carbon could be used as a good source for pyrolysis.

\section{Antimicrobial Activity \\ Antibacterial Activity}

Evaluation of antibacterial activity of the six chosen samples was carried out via disc diffusion method. Table 3 presents antibacterial activity of all samples against the two bacterial strains in which sample 5 displayed $19 \mathrm{~mm}$ highest inhibition effect against E. coli and $17 \mathrm{~mm}$ against $S$. aureus. In this research the bioactive compounds for instance tannins and flavonoids were detected in peel solutions that are mainly responsible for antibacterial activity of banana peels as reported in literature [17].

In this research banana peel DMSO solutions antibacterial activity was carried out for the first time. However, several researchers worked on antibacterial activity of various extracts of banana peel like Mokbel et al., determined antimicrobial activity of ethyl acetate extracts of fresh banana peels and studied the minimum inhibitory concentration of isolated components obtained from banana peel extracts against gram positive and gram negative bacterial species [29]. Chabuck et al., [17] worked on antibacterial activity of aqueous extract of banana peel and found that the aqueous extract of banana peel gave good results for $S$. aureus while found ineffective for $E$. coli. in

Table 3. Antibacterial activity by disc diffusion method.

\begin{tabular}{|c|c|c|}
\hline Samples & E. coli & S. aureus \\
\hline Ciprofloxacin (Positive control) & $24 \mathrm{~mm}$ & $24 \mathrm{~mm}$ \\
\hline Sample 1 & $15 \mathrm{~mm}$ & $13 \mathrm{~mm}$ \\
\hline Sample 2 & $14 \mathrm{~mm}$ & $14 \mathrm{~mm}$ \\
\hline Sample 3 & $11 \mathrm{~mm}$ & $16 \mathrm{~mm}$ \\
\hline Sample 4 & $13 \mathrm{~mm}$ & $9 \mathrm{~mm}$ \\
\hline Sample 5 & $19 \mathrm{~mm}$ & $17 \mathrm{~mm}$ \\
\hline Sample 6 & $13 \mathrm{~mm}$ & $14 \mathrm{~mm}$ \\
\hline
\end{tabular}


Table 4. Antifungal activity of Banana peel solutions.

\begin{tabular}{|c|c|c|}
\hline Samples & Control & Aspergillus niger \\
\hline Sample 1 & No inhibitory effect & No inhibitory effect \\
\hline Sample 2 & No inhibitory effect & No inhibitory effect \\
\hline Sample 3 & No inhibitory effect & No inhibitory effect \\
\hline Sample 4 & No inhibitory effect & No inhibitory effect \\
\hline Sample 5 & No inhibitory effect & No inhibitory effect \\
\hline Sample 6 & No inhibitory effect & No inhibitory effect \\
\hline
\end{tabular}

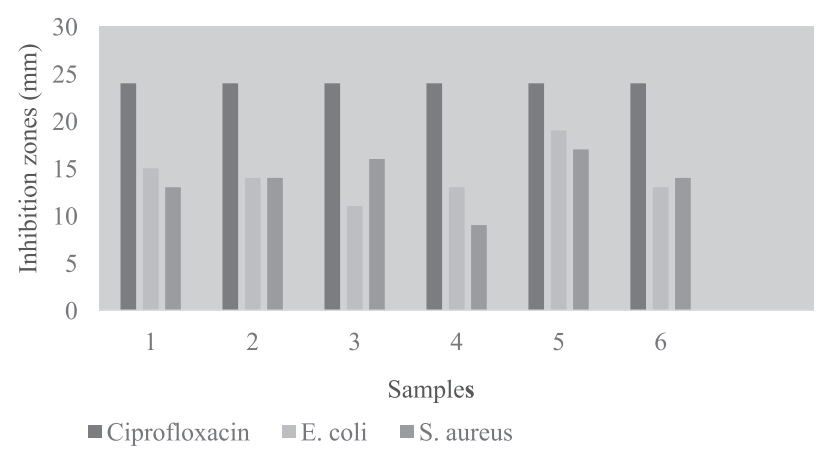

Fig. 2. Antibacterial activity of banana peel.

their research whereas Jain et al., [24] investigated antibacterial activity of banana peel extract with ethyl acetate and ethanol and their results are agreed with the present study. However, up till now no such research on banana peel has been done in Pakistan and further investigations are still required to be done on it.

\section{Antifungal Activity}

Table 4 represents antifungal activity of banana peel solutions carried out through poisoned food technique and agar well assay. The test solutions examined against Aspergillus niger were found ineffective because peel solutions did not inhibit fungus growth on potato dextrose agar.

The results are in agreement with the previous research [26] in which antifungal activity of banana peel powder and ash of three species (Musa parasiadica, Musa acuminata nendra Musa acuminata cavendish) were investigated but only extracts of Musa parasiadica peel ash and powder were found effective against the Aspergillus niger. However, evaluation of the antifungal activity of banana peel solutions against other fungi for instance Penicillium spp, Aspergillus flavus and yeast requires more investigations.

\section{Determination of Elements Concentration by Atomic Absorption}

Table 2 represents the concentrations of $\mathrm{Fe}$ that performs vital role in human metabolism. In all banana peels samples, highest concentration (3.5438 ppm) is displayed by sample 1 . Fe acceptable limit recommended by WHO is $20 \mathrm{mg} / \mathrm{kg}$ for medicinal plants and 10-28 mg/day for human consumption [30].

$\mathrm{Cu}$ concentration of the test samples is shown in Table 2 in which sample 6 expressed higher values $(0.4597 \mathrm{ppm}) . \mathrm{Cu}$ is essential for humans and plants development process and its deficiency causes anemia, cardiovascular diseases, bone abnormalities etc. [21].

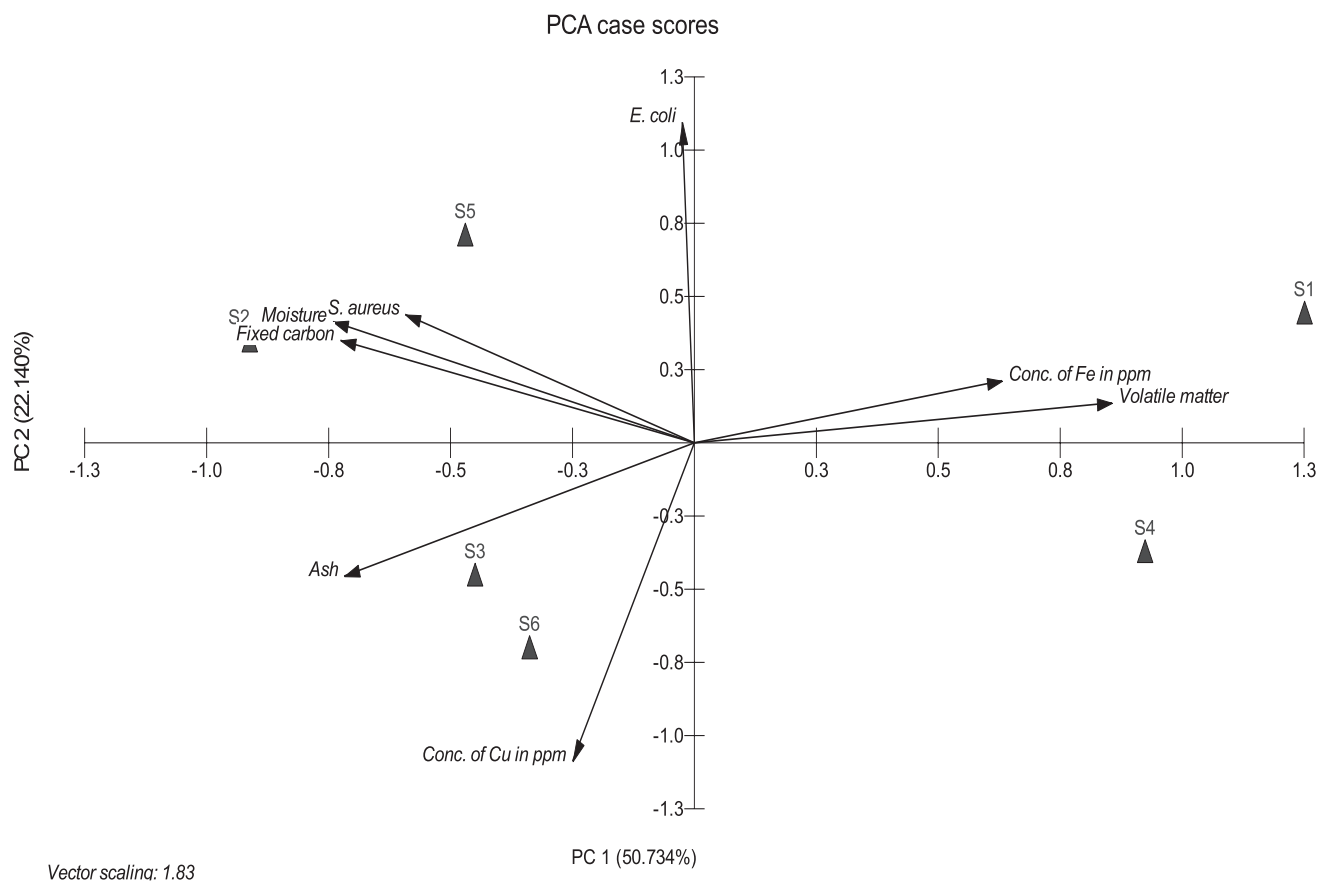

Fig. 3. Principle component analysis of all the variables. 
$\mathrm{Cu}$ permissible limit by WHO is $10 \mathrm{mg} / \mathrm{kg}$ for medicinal plants and 2-3 mg/day for human consumption.

On the basis of antibacterial properties along with the acceptable amount of $\mathrm{Fe}$ and $\mathrm{Cu}$, banana peel extract could play a very important role in therapeutic treatments as reported in literature as well [17].

\section{Principal Component Analysis}

Principal component analysis (PCA), a multivariate statistical technique, analyzes a data table representing observations depicted by many dependent variables which are inter-correlated. Its purpose is to extract the significant information from the data table and to express this information as a set of new orthogonal variables called principal components [31]. The Euclidean plot obtained from the PCA is displayed in Fig. 3. Three principal components identified in PCA had a contribution of $97.475 \%$ to its total variance. PC1 explained 50.734\% variance, PC2 showed 22.14\% variance and PC3 demonstrated $14.202 \%$ variance. The first component $\mathrm{PC} 1$ is positively correlated with volatile matter and concentration of $\mathrm{Fe}$ and negatively associated with moisture, ash, fixed carbon, $S$. aureus and concentration of $\mathrm{Cu}$. The second component PC2 is positively associated with moisture, fixed carbon, $E$. coli, $S$. aureus and concentration of Fe and negatively correlated with ash and concentration of $\mathrm{Cu}$. Similarly, PC3 showed positive correlation with moisture, ash, $S$. aureus and concentration of $\mathrm{Fe}$ and negative correlation with volatile matter, fixed carbon, E. coli and concentration of $\mathrm{Cu}$. PCA elucidation plot divides the overall data into three main groups. The first group includes S1 and S4 that are correlated with volatile matter and concentration of $\mathrm{Fe}$. The second group includes S2 and S5 which are associated with moisture, E. coli, S. aureus and fixed carbon whereas the third group includes S3 and S6 that show correlation with ash and concentration of $\mathrm{Cu}$.

\section{Conclusion}

Phytochemical and antimicrobial activities of banana peel solutions are examined in this research which indicate that all the chosen samples of banana peels carried tannins, carbohydrates, flavonoids, glycosides, phenols and steroids whereas some samples also contained $\mathrm{NaOH}$ and terpenoids. The peel solutions showed significant antibacterial activity against bacterial strains however, they were ineffective towards fungal strains. Moreover, the peel powder's proximate analysis showed that valuable bioproducts can be prepared from banana peels due to high volatile matter and fixed carbon contents and low ash and moisture contents. In addition to this, in the study concentration of elements such as $\mathrm{Fe}$ (iron) and $\mathrm{Cu}$ (copper) were detected within the permissible ranges through evaluation which revealed that for various ailments the peels, either used with other medicinal plants or alone, are completely safe.

\section{Acknowledgement}

We are thankful to Department of Biochemistry, Department of Microbiology, University of Balochistan and Department of Virology, CASVAB university for their help and support and especial thanks to Department of Chemistry, Sardar Bahadur Khan Women's University for facilitating this study.

\section{Conflict of Interest}

The authors declare no conflict of interest.

\section{References}

1. KHALID A., URREHMAN U., SETHI A., KHILJI S., FATIMA U., KHAN M., KHAN HM., NAJAM-USSAQIB Q., HASSHAM M., BIN ASAD MH., FARZANA K., MAHMOOD S., WASEEM A., ISMAIL T., MURTAZA G. Antimicrobial activity analysis of extracts of Acacia modesta, Artimisia absinthium, Nigella sativa and Saussurea lappa against Gram positive and Gram negative microorganisms. Afr. J. Biotechnol. 10, 4574, 2011.

2. MANIYAN A., JOHN R., MATHEW A. Evaluation of fruit peels for some selected nutritional and anti-nutritional factors. Emergent Life Sci. Res. 1, 13, 2015.

3. WASEEM A., ARSHAD J., IQBAL F., SAJJAD A., MEHMOOD Z., MURTAZA G. Pollution status of Pakistan: a retrospective review on heavy metal contamination of water, soil, and vegetables. BioMed research international. 2014.

4. UMMARAT N., MATSUMOTO T.K., WALL M.M., SERAYPHEAP $\mathrm{K}$. Changes in antioxidants and fruit quality in hot water-treated 'Hom Thong'banana fruit during storage. Sci Hortic. 130 (4), 801, 2011.

5. ANWAR J., SHAFIQUE U., SALMAN M., DAR A., ANWAR S. Removal of $\mathrm{Pb}$ (II) and Cd (II) from water by adsorption on peels of banana. Bioresour. Technol. 101 (6), 1752, 2010.

6. CHOEHOM R., KETSA S., VAN DOORN W.G. Senescent spotting of banana peel is inhibited by modified atmosphere packaging. Postharvest Biol. Technol. 31 (2), 167, 2004.

7. ACHAK M., HAFIDI A., OUAZZANI N., SAYADI S., MANDI L. Low cost biosorbent "banana peel" for the removal of phenolic compounds from olive mill wastewater: Kinetic and equilibrium studies. J. Hazard. Mater. 166 (1), 117, 2009.

8. AMELA K., HASSEN M.A., KERROUM D. Isotherm and kinetics study of biosorption of cationic dye onto banana peel. Energy Procedia, 19, 286, 2012.

9. EMAGA T.H., ROBERT C., RONKART S.N., WATHELET B., PAQUOT M. Dietary fibre components and pectin chemical features of peels during ripening in banana and plantain varieties. Bioresour. Technol. 99 (10), 4346, 2008. 
10. LIU C., NGO H.H., GUO W., TUNG K-L. Optimal conditions for preparation of banana peels, sugarcane bagasse and watermelon rind in removing copper from water. Bioresour. Technol. 119, 349, 2012.

11. CASTRO R.S., CAETANO L., FERREIRA G., PADILHA P.M., SAEKI M.J., ZARA LF., MARTINES M. A. U., CASTRO G.R. Banana peel applied to the solid phase extraction of copper and lead from river water: preconcentration of metal ions with a fruit waste. Ind. Eng. Chem. Res. 50 (6), 3446, 2011.

12. BABU M.A., SURIYAKALA M., GOTHANDAM K. Varietal impact on phytochemical contents and antioxidant properties of Musa acuminata (banana). J. Pharm. Sci. Res. 4 (10), 1950, 2012.

13. CHUGH C.A., MEHTA S., DUA H. Phytochemical screening and evaluation of biological activities of some medicinal plants of Phagwara, Punjab. Asian J. Chem. 24 (12), 5903, 2012.

14. WADOOD A., GHUFRAN M., JAMAL S.B., NAEEM M., KHAN A., GHAFFAR R. Phytochemical analysis of medicinal plants occurring in local area of Mardan. Biochem. Anal Biochem. 2 (4), 1, 2013.

15. YADAV R., AGARWALA M. Phytochemical analysis of some medicinal plants. J. Phytol. 3 (12), 10, 2011.

16. SAHREEN S., KHAN M.R., KHAN R.A., SHAH N.A. Estimation of flavoniods, antimicrobial, antitumor and anticancer activity of Carissa opaca fruits. BMC complementary Altern. Med. 13 (1), 372, 2013.

17. CHABUCK Z.A.G., AL-CHARRAKH A.H., HINDI N.K.K., HINDI S.K.K. Antimicrobial effect of aqueous banana peel extract, Iraq. Res. Gate: Pharm. Sci. 1, 73, 2013.

18. PARASHAR S., SHARMA H., GARG M. Antimicrobial and antioxidant activities of fruits and vegetable peels: A review. J. Pharmacogn. Phytochem. 3 (1), 2014.

19. KABENGE I., OMULO G., BANADDA N., SEAY J., ZZIWA A., KIGGUNDU N. Characterization of banana peels wastes as potential slow pyrolysis feedstock. J. Sustainable Dev. 2, 14, 2018.

20. PATHAK P.D., MANDAVGANE S.A., KULKARNI B.D. Fruit peel waste: Characterization and its potential uses. Curr. Sci. 113 (3), 444, 2017.

21. ANHWANGE B., UGYE T., NYIAATAGHER T. Chemical composition of Musa sapientum (banana) peels. J. Food Technol. 6 (6), 263, 2008.
22. EHIOWEMWENGUAN G., EMOGHENE A., INETIANBOR J. Antibacterial and phytochemical analysis of Banana fruit peel. IOSR J. Pharm. 4 (8), 18, 2014.

23. VIENA V., WARDANI S. Application of banana peels waste as adsorbents for the removal of $\mathrm{CO}_{2}, \mathrm{NO}, \mathrm{NOx}$, and $\mathrm{SO}_{2}$ gases from motorcycle emissions. Mater. Sci. Eng. 334 (1), 1, 2018.

24. JAIN P., BHUIYAN M.H., HOSSAIN K.R., BACHAR S.C. Antibacterial and antioxidant activities of local seeded banana fruits. Afr. J. Pharm. and Pharmacol. 5 (11), 1398, 2011.

25. ALI-SHTAYEH M., ABU GHDEIB S.I. Antifungal activity of plant extracts against dermatophytes. Mycoses, 42 (11-12), 665, 1999.

26. PRAKASH B., CH S., MELAPPA G., GAVIMATH C. Evaluation of Antifungal activity of Banana peel against Scalp Fungi. Mater. Today: Proc. 4 (11), 11977, 2017.

27. NAIR R.K., HARIDAS A., EZHUTHUPURAKKAL D.R. Diversity and comparative account on phytochemical and antioxidant properties of two varieties of Musa, Nendran and Kunnan. South Indian J. Biol. Sci. 2 (1), 203, 2016.

28. SIDDIQUE S., NAWAZ S., MUHAMMAD F., AKHTAR B., ASLAM B. Phytochemical screening and in-vitro evaluation of pharmacological activities of peels of Musa sapientum and Carica papaya fruit. Nat. Prod. Res. 32 (11), 1333, 2018.

29. MOKBEL M.S., HASHINAGA F. Antibacterial and antioxidant activities of banana (Musa, AAA cv. Cavendish) fruits peel. Am. J. Biochem. Biotechnol. 1 (3), $125,2005$.

30. SHAH A., NIAZ A., ULLAH N., REHMAN A., AKHLAQ M., ZAKIR M., SULEMAN KHAN M. Comparative study of heavy metals in soil and selected medicinal plants. J. Chem. 2013.

31. RIZWAN S., BENINCASA C., MEHMOOD K., ANJUM S., MEHMOOD Z., ALIZAI GH., AZAM M., PERRI E., SAJJAD A. Fatty Acids and Phenolic Profiles of Extravirgin Olive Oils from Selected Italian Cultivars Introduced in Southwestern Province of Pakistan. J. Oleo Sci. 68 (1), 33, 2019. 